\title{
2-D Crustal thermal structure along Thuadara-Sindad DSS profile across Narmada-Son lineament, central India
}

\author{
S N RAI* and S THIAGARAJAN \\ National Geophysical Research Institute, Hyderabad 500 007, India. \\ e-mail:snrai@ngri.res.in_snrai_ngri@yahoo.co.in
}

\begin{abstract}
Central India is traversed by a WSW-ENE trending Narmada-Son lineament (NSL) which is characterized by the presence of numerous hot springs, feeder dykes for Deccan Traps and seismicity all along its length. It is divided in two parts by the Barwani-Sukta Fault (BSF). To the west of this fault a graben exists, whereas to the east the basement is uplifted between Narmada North Fault (NNF) and Narmada South Fault (NSF). The present work deals with the 2-D thermal modeling to delineate the crustal thermal structure of the western part of NSL region along the Thuadara-Sindad Deep Seismic Sounding (DSS) profile which runs almost in the N-S direction across the NSL. Numerical results of the model reveal that the conductive surface heat flow value in the region under consideration varies between 45 and $47 \mathrm{~mW} / \mathrm{m}^{2}$. Out of which $23 \mathrm{~mW} / \mathrm{m}^{2}$ is the contribution from the mantle heat flow and the remaining from within the crust. The Curie depth is found to vary between 46 and $47 \mathrm{~km}$ and is in close agreement with the earlier reported Curie depth estimated from the analysis of MAGSAT data. The Moho temperature varies between 470 and $500^{\circ} \mathrm{C}$. This study suggests that this western part of central Indian region is characterized by low mantle heat flow which in turn makes the lower crust brittle and amenable to the occurrence of deep focused earthquakes such as Satpura (1938) earthquake.
\end{abstract}

\section{Introduction}

The NSL is a well-defined geological feature in central India extending about $1600 \mathrm{~km}$ from Bharuch on the western coast towards the NE underneath the Monghyr-Saharsa ridge between 72 to $88^{\circ} \mathrm{E}$ and $21^{\circ} 30^{\prime}$ to $24^{\circ} \mathrm{N}$. Mishra (1977) has suggested the possible extension of NSL westward into the Arabian Sea and eastward up to the Shillong plateau. It is believed to have originated during the middle to late Archaean period and has influenced the deposition of Neoproterozoic Vindhyan sediments to its north and Gondwana sediments to its south (West 1962; Radhakrishna 1989). The unusual features of NSL compared to other parts of the Indian shield are the occurrence of deeper earthquakes, namely the 1938
Satpura earthquake $\left(21^{\circ} 32^{\prime} \mathrm{N}, 75^{\circ} 50^{\prime} \mathrm{E}\right)$ and the 1997 Jabalpur earthquake $\left(23^{\circ} 5^{\prime} \mathrm{N}, 80^{\circ} 2^{\prime} \mathrm{E}\right)$ with focal depths $(>35 \mathrm{~km})$ in the lower crust while focal depths of most of Indian shield earthquakes are confined to $10 \mathrm{~km}$ (Mukherjee 1942; Rao et al 2002; Rajendran and Rajendran 1998; Gahalaut et al 2004). Several geological and geophysical studies have been carried out to understand the evolution of NSL and its influence on tectonic framework of central India. These studies include four Deep Seismic Sounding (DSS) profiles namely (I) HirapurMandla, (II) Khajuriakalan-Pulgaon, (III) UjjainMahan, and (IV) Thuadara-Sindad (Kumar et al 2000; Tewari et al 2001; Sridhar and Tewari 2001; Kumar 2002; Mall et al 2002). Locations of these profiles are shown in figure 1. From the analysis of geological and geophysical data, it has been

Keywords. 2-D thermal modeling; surface heat flow; crustal thermal structure; Curie depth, Narmada-Son lineament; Moho temperature. 


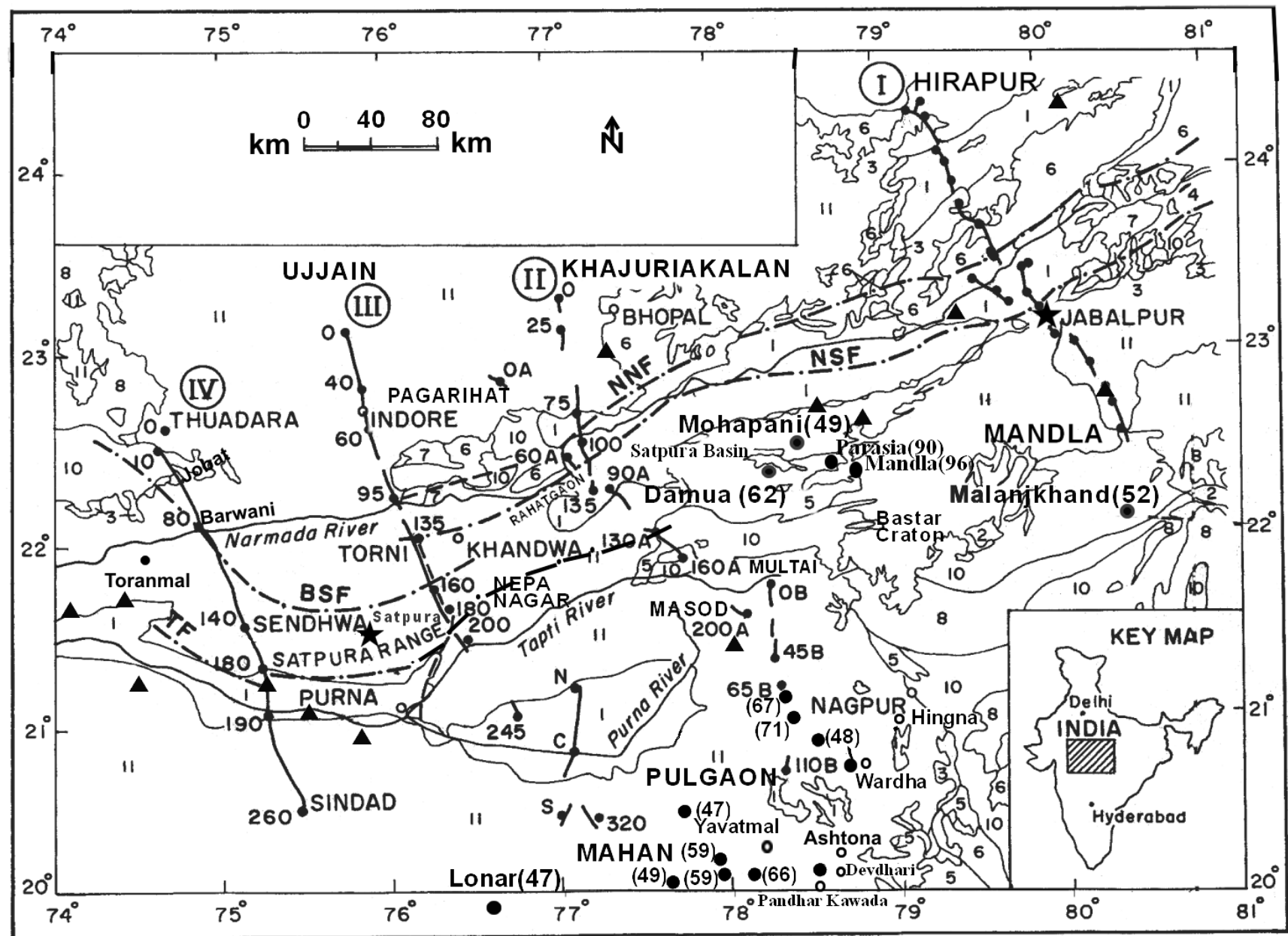

\begin{tabular}{|c|c|}
\hline 1 & Recent \\
\hline 2 & Pleistocene \\
\hline 3 & Upper Cretaceous \\
\hline 4 & U.Carboniferous-L.Cretaceous \\
\hline 5 & Permian Carboniferous \\
\hline 6 & Meso-Neo-Proterozoic \\
\hline 7 & Meso-Proterozoic \\
\hline
\end{tabular}

LEGEND
\begin{tabular}{|c|l}
\hline 8 & Palaeo Proterozoic \\
\hline 9 & Archoean (Intrusive) \\
\hline 10 & Archaean \\
\hline 11 & Deccon Trap ( $66 \mathrm{Ma})$ \\
$9(52)$ Heat flow value \\
$\star \quad$ Earthquake
\end{tabular}

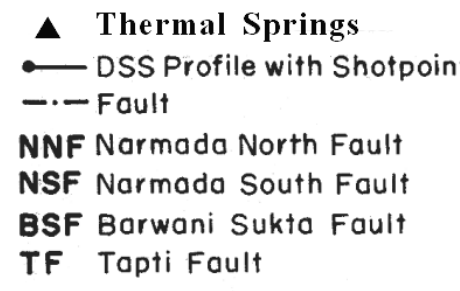

Figure 1. Geological and tectonic map of Narmada-Son lineaments with locations of DSS profiles and heat flow sites (modified after Sridhar and Tewari 2001).

suggested that the NSL is divided by a curvilinear Barwani-Sukta fault which is marked by shearing and brecciation of basalt, alignment of hot springs, and presence of earthquake epicenters (Sridhar 2001; Tewari et al 2002). The southwestern part represents a graben and the northeastern part a basement uplift bounded by deep-seated Narmada North Fault (NNF) and Narmda South Fault (NSF) (figure 1). The first three DSS profiles traverse the region of basement uplift while the last one profile traverses the region of graben.

This paper deals with 2-D thermal modeling along the $260 \mathrm{~km}$ long Thuadara-Sindad DSS profile. The 2-D modeling approach needs 2-D crustal structure up to the Moho and $P$-wave velocity distribution for construction of the model and for estimation of heat production in the middle and lower crust respectively, by using an empirical relationship between heat production $(A)$ and $P$-wave velocity $\left(V_{p}\right)$.

\section{Geology and tectonic frame work}

The region of Thuadara-Sindad DSS profile is mostly covered by Deccan Traps. The Deccan Volcanic rocks are predominantly Fe-rich tholeiites formed at the Cretaceous Tertiary boundary ( $65 \mathrm{Ma}$ ago) (Courtillot 1994; Mahoney et al 2000). Other geological formations exposed in the northern part include marine Cretaceous deposits belonging to the Bagh group, Lameta beds 


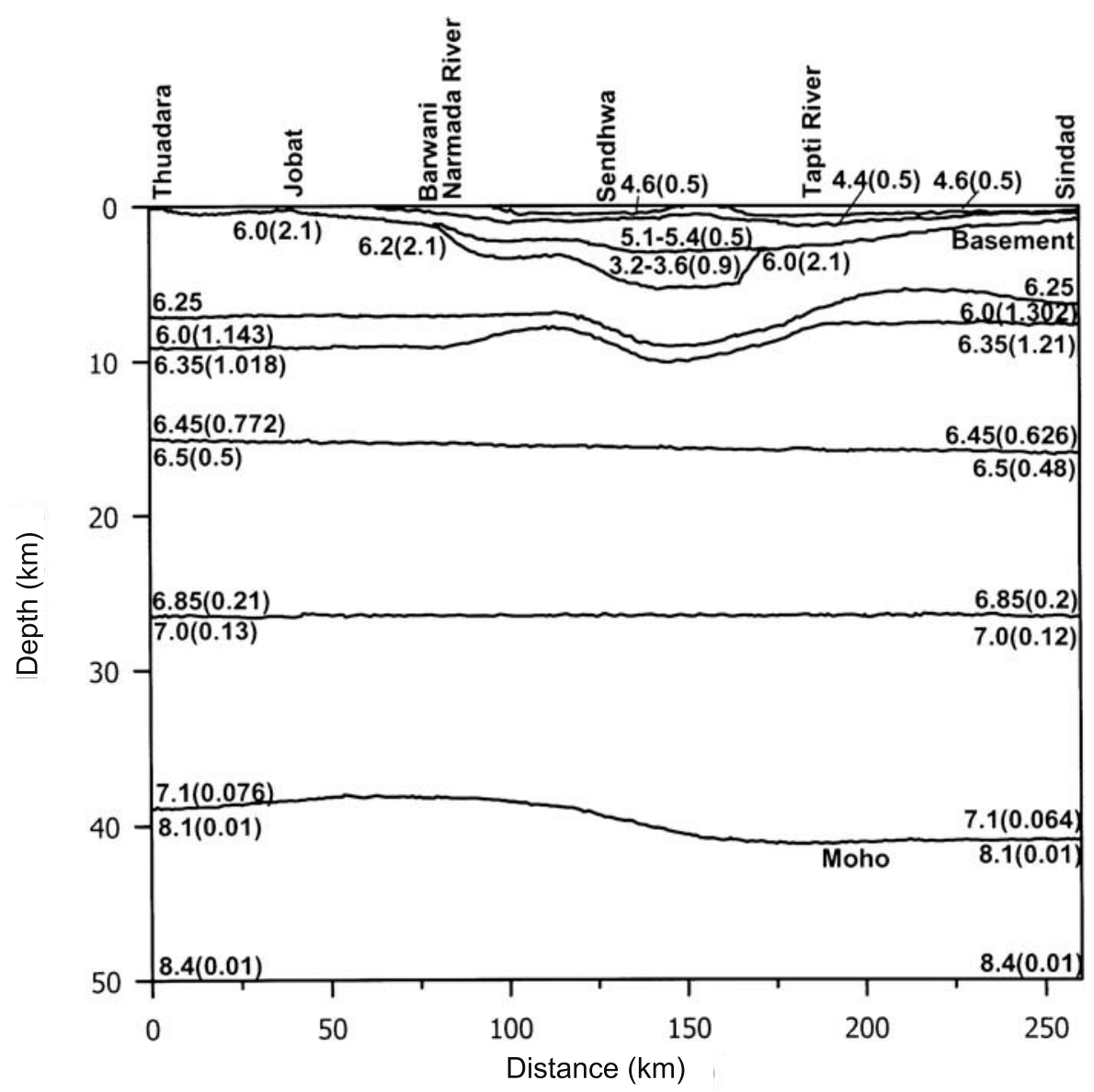

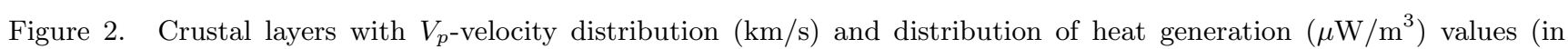
brackets) along the profile.

(Mesozoics), the Aravalli and granitic gneisses. The Bagh fauna has close affinities with that of the Cretaceous fauna of Gujarat in western India. So it can be presumed that the lower reaches of the Narmada River was a low depression between Satpuras and the Vindhyans during Bagh times and an arm of the sea encroached the Narmada Son lineament in the form of a marine transgression (Sridhar 2001). The southern part of Thuadara-Sindad profile is traversed by an E-W trending Tapti fault which marks the southern boundary of the Satpura ranges and northern boundary of Tapti Alluvium. The Satpura range between the Narmada and Tapti Rivers is considered as a horst based on broad gravity high (Qureshy 1964). The Satpura horst is bounded by Son-Narmada and Tapti faults in the north and south, respectively. These faults have given rise to two rift valleys on both sides of the horst. The Narmada and Tapti Rivers flow in these rift valleys. For completeness of the work a brief description of the crustal structure and $P$-wave velocity distribution along the ThuadaraSindad profile, given by Sridhar (2001); Sridhar and Tewari (2001); and Tewari and Kumar (2003) is presented in the next section.

\section{Crustal structure and $P$-wave velocity distribution}

The crustal structure and $P$-wave velocity distribution along the Thuadara-Sindad profile is shown in figure 2. The interpretation of seismic data along this profile reveals a sedimentary graben between the Narmada and Tapti Rivers (Sridhar 2001; Sridhar and Tewari 2001). Within the graben the depth to the basement $\left(6.0-6.2 \mathrm{~km} \mathrm{~s}^{-1}\right)$ is about $3000 \mathrm{~m}$ between the Narmada River and Sendhwa and $5000-5500 \mathrm{~m}$ between the Sendhwa and Tapti River. This graben contains 1000-2800 m thick low velocity (velocity $3.2-3.6 \mathrm{~km} \mathrm{~s}^{-1}$ ) sediments under a thick cover (max $\sim 2500 \mathrm{~m}$ ) of the Deccan Traps $\left(4.4-5.4 \mathrm{~km} \mathrm{~s}^{-1}\right)$. The graben is bounded by the Barwani-Sukta fault in the north and Tapti fault in the south (figure 1). Below the basement layer lies a low velocity $\left(6.0 \mathrm{~km} \mathrm{~s}^{-1}\right)$ zone of $\sim 2 \mathrm{~km}$ thickness. Below this layer two more layers with velocity in the range of $6.35-6.45 \mathrm{~km} \mathrm{~s}^{-1}$ and $6.5-6.85 \mathrm{~km} \mathrm{~s}^{-1}$ have been identified. A high velocity (7.0$7.1 \mathrm{~km} \mathrm{~s}^{-1}$ ) mafic underplating layer exists at a depth of about $27 \mathrm{~km}$. Its lower boundary forms the Moho depth which varies between 38 and $42 \mathrm{~km}$. 


\section{Mathematical modeling}

Conduction is the most dominant process of heat transfer in solid materials. Hence, this mode of heat transfer is generally considered in crustal thermal modeling. A finite element based numerical program named Numerically Integrated System Analysis (NISA), is used for computation of the 2-D crustal thermal structure by solving the 2-D steady state heat conduction equation (Rai and Thiagarajan 2006). For modeling purpose the entire area of the model is divided into a network of four nodes quadrilateral elements with $10 \mathrm{~km}$ length in X-direction. Because of the more inhomogeneous character of the upper crustal layer, the region between ground surface and $10 \mathrm{~km}$ depths are divided into relatively smaller elements. The width of the elements in the Z-direction is $500 \mathrm{~m}$ for the first $10 \mathrm{~km}$ while it is $2 \mathrm{~km}$ below it. The depth of the lower boundary of the model is taken at $50 \mathrm{~km}$ which is below the Moho. One should know distribution of heat generation $(A)$, and thermal conductivity $(K)$ within the region to be modeled for computation of temperature distribution.

With the precise knowledge of $P$-wave velocity distribution available from the DSS studies the distribution of heat generation $A$, in the middle and lower crustal layer is estimated from $P$-wave velocity value by using the following empirical relationship between $P$-wave seismic velocity $\left(V_{p}\right)$ and radiogenic heat generation $(A)$ for Precambrian rocks (Rybach and Buntebarth 1984; Cermak 1989):

$$
\ln A=12.6-2.17 V_{p},
$$

where $A$ is in $\mu \mathrm{W} / \mathrm{m}^{3}$ and $V_{p}(20,100)$ is the velocity $(\mathrm{km} / \mathrm{s})$ at room temperature $20^{\circ} \mathrm{C}$ and pressure $100 \mathrm{MPa}$. The estimated value of $A$ is corrected for in-situ pressure and temperature conditions by using a correction factor as suggested by Cermak (1989). However, this conversion relationship between $V_{p}$ and $A(X, Z)$ is not applicable in the upper crustal layer because the upper crust is highly heterogeneous due to the presence of micro cracks which facilitate the redistribution of radioactive elements by groundwater movement. This may have considerably altered the original distribution of the radioactive content of rocks (Cermak 1989). The heat production values of the top layers of Deccan volcanic and sedimentary rocks up to the basement are taken as constant. For the NSL region, heat production for sedimentary layer $\left(3.2-3.6 \mathrm{~km} \mathrm{~s}^{-1}\right)$ is taken equal to $0.9 \mu \mathrm{W} / \mathrm{m}^{3}$ which is the mean of heat production of sandstone, clay and limestone (Rybach and Cermak 1982). Concentrations of U, Th, and K in the Basaltic volcanic rock of the region have been reported by Chandrasekaram et al 1999; Mahoney et al 2000 and Sheth et al 2004. In this paper, the heat generation value equal to $0.5 \mu \mathrm{W} / \mathrm{m}^{3}$ for Deccan volcanic layer $\left(4.4-5.4 \mathrm{~km} \mathrm{~s}^{-1}\right)$ is taken as the mean of heat generation values estimated at $210 \mathrm{~m}$ and $1100 \mathrm{~m}$ depths from $\mathrm{U}, \mathrm{Th}, \mathrm{K}$ concentration values given by Mahoney et al (2000) for tholeiitic flood basalts from Toranmal $\left(21^{\circ} 53^{\prime} \mathrm{N}, 74^{\circ} 28^{\prime} \mathrm{E}\right)$ area located near the profile on its western side. The heat generation value is estimated by using the following conversion factor (Birch 1954):

$$
\begin{aligned}
& \operatorname{HP}\left(\mu \mathrm{W} / \mathrm{m}^{3}\right) \\
& \quad=\rho\left(0.035 \mathrm{C}_{\mathrm{K}}+0.097 \mathrm{C}_{\mathrm{U}}+0.026 \mathrm{C}_{\mathrm{Th}}\right),
\end{aligned}
$$

where $\rho$ is the density of the rocks in $\mathrm{g} \mathrm{cm}^{-3} ; \mathrm{C}_{\mathrm{K}}$, $\mathrm{C}_{\mathrm{U}}$, and $\mathrm{C}_{\mathrm{Th}}$ refer to $\mathrm{K}, \mathrm{U}$, and Th concentrations by weight ( $\mathrm{K}$ in $\%, \mathrm{U}$ and $\mathrm{Th}$ in $\mathrm{ppm}$ ), the numerical constant 0.035 refers to heat production $\left(10^{-12} \mathrm{~W}\right)$ per gram of rock per $1 \%$ of $\mathrm{K}$, and the constants 0.097 and 0.026 refer to heat production $\left(10^{-12} \mathrm{~W}\right)$ per gram of rock, per $1 \mathrm{ppm}$ of $\mathrm{U}$ and $1 \mathrm{ppm}$ of Th, respectively. The density of rock, $\rho$, is taken equal to $2.8 \mathrm{~g} \mathrm{~m}^{-3}$ for Deccan volcanic rocks (Ray et al 2007).

The heat generation value between upper and lower boundaries of basement rocks is estimated by using an exponential model of radiogenic heat source which is defined by (Lachenbruch 1970).

$$
A(Z)=A_{0} \exp (-Z / D)
$$

in which $A_{0}$ is the heat production of the basement rock, and $D$ is the logarithmic decrement which represents thickness of the radioactive enriched crustal layer. In this case $a<Z<b \mathrm{~km}$ where $a$ and $b$ are the depth of upper and lower boundaries of the basement layer. $A_{0}$ and $D$ values for the NSL are not available. However, Gupta et al (1993) have reported these values for the granodiorite rock from Malanjkhand $\left(22.026^{\circ} \mathrm{N}, 80.715^{\circ} \mathrm{E}\right)$ located south of NSL in Bastar craton (figure 1). These values are: $A_{0}=2.1 \mu \mathrm{W} / \mathrm{m}^{3}, D=11.5 \mathrm{~km}$ and $K_{0}=3.1 \mathrm{Wm}^{-1} \mathrm{~K}^{-1}$. These values for $A_{0}, K_{0}$ and $D$ have been used in this study to also estimate the heat generation distribution from the top of the basement rock to the top of the LVZ. Gupta et al (1993) have also given mantle heat flow value equal to $23 \mathrm{~mW} / \mathrm{m}^{2}$ for the Bastar craton and the same value has been considered in the present study at the base of the model as a boundary condition. Since heat production in the upper mantle is very small, a small value of $A$ equal to $0.01 \mu \mathrm{W} / \mathrm{m}^{3}$ is assigned to the region beneath the Moho (Safanda et al 1992). The calculated values of $A$ are assigned 
Table 1. Temperature dependent thermal conductivity values.

\begin{tabular}{lcll}
\hline & $K_{0}\left(\mathrm{Wm}^{-1} \mathrm{~K}^{-1}\right)$ & $T\left({ }^{\circ} \mathrm{C}\right)$ & $C\left(\mathrm{~K}^{-1}\right)$ \\
\hline Upper crust & 3.1 & $<300$ & 0.001 \\
Lower crust & 2.0 & $300-500$ & 0.0 \\
Lithospheric & 2.5 & $>500$ & -0.00025 \\
mantle & & & \\
\hline
\end{tabular}

within the model area according to the distribution of corresponding $V_{p}$ velocities. Distributions of estimated heat generation values are shown within the brackets in figure 2 .

In this study thermal conductivity has been considered as a function of temperature defined by Cermak and Bodri (1986); Shengbiao and Jiyang (2000):

$$
K=\frac{K_{0}}{(1+C T)},
$$

in which $K_{0}$ is the thermal conductivity at surface condition and $C$ is an experimentally determined constant which controls the behaviour of $K$ with temperature $T$. The values of $K_{0}$ and $C$ used in the computation are given in table 1 .

With these known values of controlling parameters, i.e., thermal conductivity $(K(X, Z))$, heat generation $(A(X, Z))$, mantle heat flow $\left(Q_{d}\right)$, length $(L)$ and depth $(d)$ of the model area, the subsurface temperature distribution is estimated by using the NISA program. More details of mathematical modeling procedure is given in Rai et al (2003) and Rai and Thiagarajan (2006).

\section{Numerical results and discussion}

The calculated surface heat flow values and isotherms along the profile are plotted in figure 3 . The numerical results indicate that the Moho temperature varies between 470 and $500^{\circ} \mathrm{C}$. The minimum value is in the northern part of the profile while the maximum value is in the southern part of the profile. The Moho temperature along this profile is found less than the Moho temperature along profiles I, II and III which is in the range of 500 to $580^{\circ} \mathrm{C}$. The heat flow value varies between 45 to $47 \mathrm{~mW} / \mathrm{m}^{2}$ with the minimum value between Sendhwa and Tapti River and maximum between Jobat and Barwani. The surface heat flow values along this profile are found to be comparatively less than those surface heat flow values $\left(46-49 \mathrm{~mW} / \mathrm{m}^{2}\right)$ along the other three profiles located in the east of BSF. The low surface heat flow between Narmada and Tapti is attributed to the presence of thick volcanic layers which have a low heat generation value compared to the basement rocks. Though the heat flow values near to this profile are not available for comparison, however, these surface heat flow values are found in close agreement with heat flow values measured at Lonar $\left(47 \mathrm{~mW} / \mathrm{m}^{2}\right)$, Satephal $\left(47 \mathrm{~mW} / \mathrm{m}^{2}\right)$ and Singdad $\left(49 \mathrm{~mW} / \mathrm{m}^{2}\right)$ in Yawatmal area near to the southern tips of profile II and Mandwa $\left(48 \mathrm{~mW} / \mathrm{m}^{2}\right)$ located very near to the Multai-Pulgaon section of the profile III in Wardha area, and Mohapani $\left(49 \mathrm{~mW} / \mathrm{m}^{2}\right)$ located in the northern tips of Satpura basin south of NSL (Gupta 1993; Roy and Rao 2000). Even south of Sindad in Ahmednagar region (around $75^{\circ} \mathrm{E}, 19-20^{\circ} \mathrm{N}$ ) low heat flow values in the range of $35-45 \mathrm{~mW} / \mathrm{m}^{2}$ (mean $40 \mathrm{~mW} / \mathrm{m}^{2}$ ) have been reported by Roy et al 1996 .

The high surface heat flow values are also observed at Wadhona $\left(71 \mathrm{~mW} / \mathrm{m}^{2}\right)$ and Palora $\left(67 \mathrm{~mW} / \mathrm{m}^{2}\right)$ located very near to the MultaiPulgoan section of profile II in Wardha region, and at Dattarampuram $\left(59 \mathrm{~mW} / \mathrm{m}^{2}\right)$, Kurha Talni $\left(66 \mathrm{~mW} / \mathrm{m}^{2}\right)$ and Loni $\left(59 \mathrm{~mW} / \mathrm{m}^{2}\right)$ in the region of NW extension of Vaidarbha Nadi coalfield of Yavatmal district as shown in figure 1 (Roy and Rao 2000). Based on geological and geophysical investigations five major troughs are inferred in Wardha and Yavatmal regions starting from the Nagpur gravity low region towards south. These troughs are: (i) Kamthi, (ii) Umrer, (iii) Bhander, (iv) Wardha-Pranhita, and (v) Vaidarbha Nadi coal field all extending in a northwesterly direction below the Deccan Traps (Joga Rao et al 1984; Chary 1993). Towards the southeastern side these troughs are connected to the probable northward extension of Pranhita-Godavari Gondwana graben through Wardha and Nagpur which abuts the NSL underneath Satpura basin (Qureshy et al 1968; Biswas 2003). These sites of high heat flow values are associated with gravity and resistivity lows indicating the presence of Gondwana sediments with fluids in general and coal seams in particular (Joga Rao et al 1984; Chary 1993; Gupta 1993). The presence of Gondwana sediments with coal seams has been confirmed by boreholes data drilled near Hingna $\left(79^{\circ} \mathrm{E}, 21^{\circ} 5^{\prime} \mathrm{N}\right)$ in Umrer trough, and Astona $\left(78^{\circ} 45^{\prime} \mathrm{E}, 20^{\circ} 15^{\prime} \mathrm{N}\right)$ in northwesterly extension of Rajur coal field of WardhaPranhita trough. On the other hand, sites of heat flow values of the order of $49 \mathrm{~mW} / \mathrm{m}^{2}$ and less at Lonar, Satephal, Singdad, and Mandwa are located at boundaries of two adjacent troughs. These boundaries are characterized with less resistivity, indicating that these values are free from the effect of hydrothermal circulation and represent the conductive surface heat flow value for NSL region in central India. 

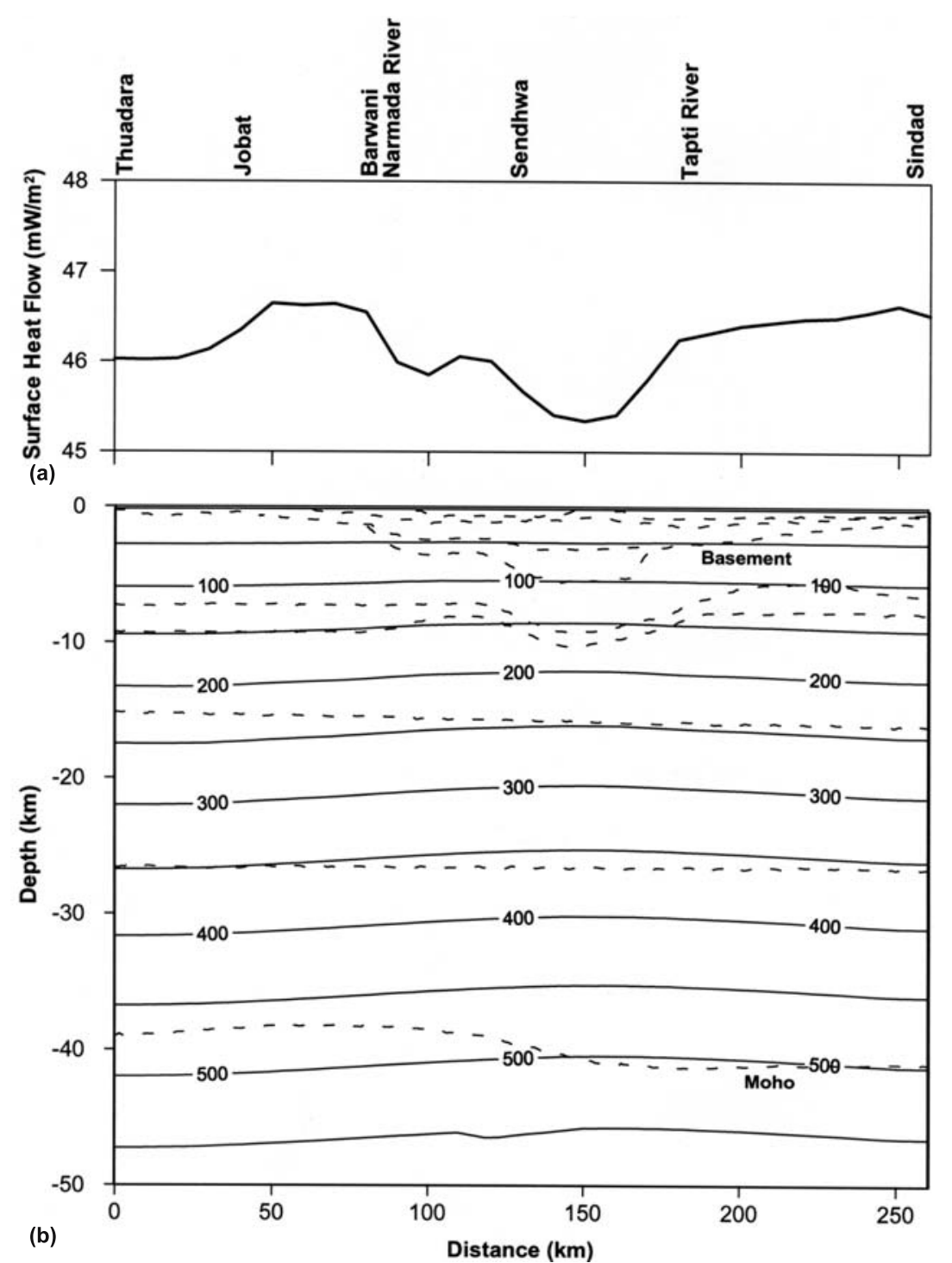

Figure 3. Calculated (a) surface heat flow values and (b) isotherms $\left({ }^{\circ} \mathrm{C}\right)$ (solid line) along with crustal structure (dotted line) along the profile.

The high surface heat flow values are also observed at Damua $\left(62 \mathrm{~mW} / \mathrm{m}^{2}\right)$, Parasia $\left(90 \mathrm{~mW} / \mathrm{m}^{2}\right)$ and Mandla $\left(96 \mathrm{~mW} / \mathrm{m}^{2}\right)$ in Pench Kanhan Valley coal field located south of NSL in Satpura basin. The presence of hot fluids in the sedimentary rocks may give rise to the high heat flow value. Basic dykes and sills which have an affinity to Deccan Traps and several faults such as Parasia fault do exist in the Satpura basin (Datta 1993; Gupta 1993; Biswas 2003). These dykes and faults control the water movement in the basin. The dyke, if located towards the down-dip side of the basin, would act as a barrier and assist upward flow of deep circulating hot water. Faults also work as conduit for the upward movement of hot water. This process would result in raising the magnitude of surface heat flow values at the above-mentioned sites similar to that reported from Ashwaraopet $\left(104 \mathrm{~mW} / \mathrm{m}^{2}\right)$ and Chintalapudi $\left(92 \mathrm{~mW} / \mathrm{m}^{2}\right)$ in Godavari Valley (Rao et al 1970; Gupta 1993). This fact is supported by the observation of heat flow rise due to hydrothermal circulation across a layer with $10^{\circ} \mathrm{C}$ temperature difference which would contribute about $40 \mathrm{~mW} / \mathrm{m}^{2}$ to the surface heat flow density value (Lachenbruch and Sass 1977). Based on the results of rheological modeling, Manglik and Singh (2002) have also suggested that occurrence of deep crustal events at $\sim 35$ $37 \mathrm{~km}$ depth such as Jabalpur and Satpura earthquakes require the surface heat flow value lower than $48 \mathrm{~mW} / \mathrm{m}^{2}$. There are several other examples of deep earthquakes $(25-40 \mathrm{~km})$ such as Saguenay (1988) in east Canada; Soleberg (1938) in Sweden; Manaus (1963) in Brazil and Brome (1979) in Australia which occurred in the areas characterized with $<50 \mathrm{~mW} / \mathrm{m}^{2}$ heat flow value (Chen 1988). 


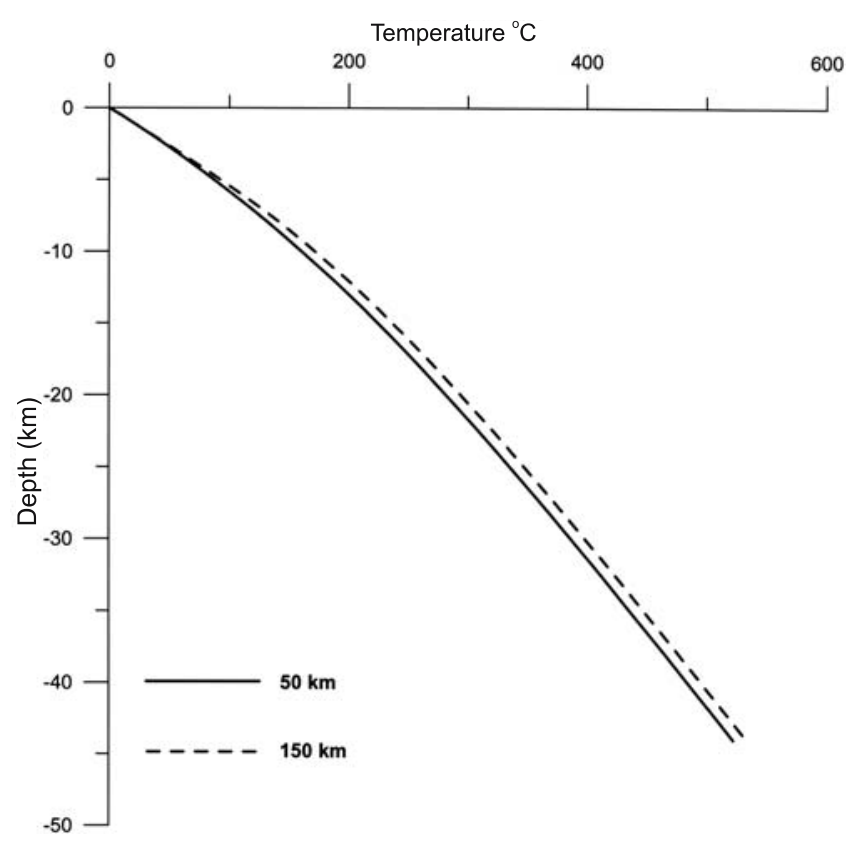

Figure 4. Calculated temperature-depth distribution at $50 \mathrm{~km}$ distance (solid line) and at $150 \mathrm{~km}$ distance (dotted line).

The Curie depth is found to vary between 46 and $47 \mathrm{~km}$ and is in close agreement with the earlier reported Curie depth $(46 \mathrm{~km})$ estimated from the analysis of MAGSAT data along the profile P208 which passes through the NSL region under consideration (Agarwal et al 1992). The Curie depth is $\sim 10 \mathrm{~km}$ below the Moho in the north of Sendhwa and is $\sim 5 \mathrm{~km}$ below the Moho in the south of Sendhwa.

Temperature of $\mathrm{B} / \mathrm{D}$ transition when compared with the maximum depth of seismicity gives a probable estimate of prevailing temperature at that depth (Manglik and Singh 2002). The most probable value adopted for the focal depth of Satpura range earthquake of 1938 is $40 \mathrm{~km}$ (Mukherjee 1942). Experimental results have shown that quartz, feldspar and olivine become ductile at $300-450^{\circ} \mathrm{C}$ and $700-750^{\circ} \mathrm{C}$ respectively, for natural strain rates (Meissner and Strehleau 1982; Chen and Molnar 1983). Therefore, temperature of $\mathrm{B} / \mathrm{D}$ transition for mafic rock should be between 450 and $700^{\circ} \mathrm{C}$. It is evident from figure 3 that the south of Sendhwa, in the region of Satpura range, the focal depth $(40 \mathrm{~km})$ of Satpura earthquake coincides with the $500^{\circ} \mathrm{C}$ isotherm which may be regarded as temperature of $\mathrm{B} / \mathrm{D}$ transition in the mafic lower crust. This depth incidentally coincides with the Moho depth. However, this is not the case north of BSF where Moho is found to be $2-3 \mathrm{~km}$ above the $500^{\circ} \mathrm{C}$ isotherm.

The calculated temperature-depth profiles at $50 \mathrm{~km}$ distance outside the graben near Jobat and at $150 \mathrm{~km}$ distance within the graben between Sendhwa and Tapti River are plotted in figure 4 . The figure illustrates the nature of variation in temperature distribution at both locations. The temperature gradient up to a characteristic depth $(11.5 \mathrm{~km})$ is around $16^{\circ} \mathrm{C} / \mathrm{km}$ and below up to the Moho is around $10.5^{\circ} \mathrm{C} / \mathrm{km}$.

There is always a possibility of uncertainty in the estimation of heat generation and thermal conductivity which is likely to affect the temperature field. By considering a 1-D homogenous crustal model of $35 \mathrm{~km}$ thickness having surface heat generation $=2.0 \mu \mathrm{Wm}^{-3}$, mantle heat flow $=25 \mathrm{~mW} / \mathrm{m}^{2}$, mean value of $\mathrm{K}=2.5 \mathrm{~W} / \mathrm{mK}$ with $0.25 \mathrm{~W} / \mathrm{mK}$ standard deviation (S.D.). Srivastava and Singh (1998) have computed mean temperature equal to $419^{\circ} \mathrm{C}$ with $44^{\circ} \mathrm{C}$ S.D. at $35 \mathrm{~km}$ depth which amounts to $\sim 10 \%$ deviation in the temperature field at Moho. Similarly by considering another 1-D crustal model of $35 \mathrm{~km}$ thickness having mantle heat flow $=23 \mathrm{~mW} / \mathrm{m}^{2}, K=3.0 \mathrm{~W} / \mathrm{mK}$, mean surface heat generation $=1.0 \mu \mathrm{Wm}^{-3}$ with $0.5 \mu \mathrm{Wm}^{-3}$ S.D., they have calculated Moho mean temperature around $482^{\circ} \mathrm{C}$ with $102^{\circ} \mathrm{C}$ S.D. which amounts to $\sim 21 \%$ deviation in the temperature field (Srivastava and Singh 1999). These results are discussed here to highlight the effects of uncertainty in heat generation and conductivity values on the temperature field.

\section{Conclusions}

The numerical results indicate that the surface heat flow value in the western part of NSL along Thuadara-Sindad profile varies between 45 and $47 \mathrm{~mW} / \mathrm{m}^{2}$ and is in close agreement with heat flow values measured at some places such as Lonar, Satephal, Singdad, Mandwa and Mohapani located south of NSL. The Curie depth is $\sim 46-47 \mathrm{~km}$ which is in close agreement with the Curie depth $(46 \mathrm{~km})$ estimated from the analysis of MAGSAT data. The calculated surface heat flow value is found to be much less than the earlier suggested values by Ravi Shanker (1988) in the range of 70$100 \mathrm{~mW} / \mathrm{m}^{2}$ for NSL region. His values are based on silica content in groundwater and mostly in the zones of upwelling thermal water. In such areas convective transfer of heat is predominant and any heat flow measurement is not reflective of conductive regional heat flow. Numerical results indicate that for surface heat flow value of the order of $70 \mathrm{~mW} / \mathrm{m}^{2}$, the mantle heat flow has to be increased to $47 \mathrm{~mW} / \mathrm{m}^{2}$. But this value of mantle heat flow gives Curie depths at $\sim 17 \mathrm{~km}$. This value does not match with the Curie depth 
( 46-47 km) estimated from the MAGSAT data. The Moho temperature varies between 470 and $500^{\circ} \mathrm{C}$, which is less than the Moho temperature reported for Cambay basin $\left(\sim 900^{\circ} \mathrm{C}\right)$ and Godavari graben/basin $\left(\sim 620^{\circ} \mathrm{C}\right)$. This indicates that the lower crust in this region is cool which in turn makes it of brittle nature amenable to the occurrence of deep focused earthquakes such as Satpura (1938).

\section{Acknowledgements}

Authors are grateful to Dr. V P Dimri, Director, NGRI, for his encouragement and kind permission to publish this work. We thank all the three reviewers and Dr. Hetu Sheth, Associate Editor for their invaluable suggestions which helped in improving the quality of the paper. Our thanks are due to the Department of Science and Technology for funding this study through Project No. ESS/16/146/2001.

\section{References}

Agrawal P K, Thakur N K and Negi J G 1992 MAGSAT data and Curie depth below Deccan Flood Basalts (India); Pageoph 138(1) 61-75.

Birch F 1954 Heat from radioactivity; In: Nuclear Geology (ed.) H. Faul (New York: John Wiely \& Sons) pp. $148-174$.

Biswas S K 2003 Regional tectonic framework of the Pranhita-Godavari basin, India; J. Asian Earth Sci. 21(6) 543-551.

Cermak V 1989 Crustal heat production and mantle heat flow in central and Eastern Europe; Tectonophys. 159 $195-215$

Cermak V and Bodri L 1986 Two-dimensional temperature modeling along five east-European geotraverses; Journal of Geodynamics 5 133-163.

Chandrasekharam D, Mahoney J J, Sheth H C and Duncan R A 1999 Elements and $\mathrm{Nd}-\mathrm{Sr}-\mathrm{Pb}$ isotope geochemistry of flows and dikes from the Tapi rift, Deccan flood basalt province, India; Journal of Volcanology and Geothermal Research 93 111-123.

Chary N R 1993 Structure tectonics and basinal history of Vaidarbha Nadi coalfield of Yavatmal district, Maharashtra; Gondwana Geological Magazine, Special Volume on Birbal Sahani centenary National Symposium on Gondwana of India, Jan. 16-17, 247-253.

Chen W P 1988 A brief update on the focal depths of intracontinental earthquakes and their correlations with heat flow and tectonic age; Seismol. Res. Lett. 59(4) 263-272.

Chen W P and Molnar P 1983 Focal depth of intracontinental and intraplate earthquakes and their implications for the thermal and mechanical properties of the lithosphere; J. Geophys. Res. 88 4183-4214.

Courtillot V 1994 Mass exinctions in the last 300 million years: One impact and seven flood basalts? Isr. J. Earth Sci. 7 91-110.

Datta J 1993 Mohapani Coal field - its structural features, associated igneous bodies and heat effect on coal seams; Gondwana Geological Magazine, Special Volume on Birbal Sahani centenary National Symposium on Gondwana of India, Jan. 16-17, 286-299.
Gahalaut V K, Rao V K and Tewari H C 2004 On the mechanism and source parameters of the deep crustal Jabalpur earthquake, India, of 1997 May 21: Constraints from aftershocks and changes in static stress; Geophysical Journal International 156 345-351.

Gupta M L 1993 Surface heat flow values in Gondwana grabens of peninsular India: Their significance and implications; Gondwana Geological Magazine, Special Volume on Birbal Sahani centenary National Symposium on Gondwana of India, Jan. 16-17, 425-437.

Gupta M L, Sundar A, Sharma S R and Singh S B 1993 Heat flow in the Bastar craton, central Indian shield: implications for thermal characteristics of Proterozoic cratons; Physics of the Earth and Planetary Interiors 78 23-31.

Joga Rao M V, Sarkar R K, Ghatak T K, Saha K and Ghosh D C 1984 Report on the geophysical investigations under deep geological project for delineation of Gondwana sediments below Deccan Traps in parts of Yavatmal district Wardha valley coal field area, Maharashtra, 1-21.

Kumar P 2002 Seismic structure of the continental crust in the central Indian region and its tectonic implications; Unpublished Ph.D. Thesis, Osmania University, pp. 140.

Kumar P, Tewari H C and Khandekar G 2000 An anomalous high-velocity layer at shallow crustal depths in the Narmada zone, India; Geophysical Journal International 142 95-107.

Lachenbruch A H 1970 Crustal temperature and heat production: implication of the linear heat flow relationship; J. Geophys. Res. 75 3291-3300.

Lachenbruch A H and Sass J H 1977 Its nature and physical properties in the Earth's crust (ed.) J G Heacock, Geophysical Monograph 20 626-675.

Mahoney J J, Sheth H C, Chandrasekharam D and Peng Z X 2000 Geochemistry of Flood Basalts of the Toranmal section, northern Deccan Traps, India: Implications for regional Deccan stratigraphy; J. Petrol. 41(7) 1099-1120.

Mall D M, Sarkar D and Reddy P R 2002 Seismic signature of sub-trappean Gondwana basin in central India; Gondwana Res. 5 613-618.

Manglik A and Singh R N 2002 Thermomechnical structure of the central Indian shield: Constraints from deep crustal seismicity; Curr. Sci. 82 1151-1157.

Meissner R and Strehleau J 1982 Limits of stresses in continental crust and their relation to the depth frequency distribution of shallow earthquakes; Tectonics 1 73-89.

Mishra D C 1977 Possible extension of the Narmada-Son lineament towards murray ridge (Arabian Sea) and the Eastern Syntaxial bend of the Himalayas; Earth Planet. Sci. Lett. 36 301-308.

Mukherjee S M 1942 Seismological features of the Satpura earthquake of the $14^{\text {th }}$ March 1938; Proc. Indian Acad. Sci. (Earth Planet Sci.) 16 167-175.

Qureshy M N 1964 Gravity anomalies as related to regional tectonics of peninsular India; Rep. $22^{\text {nd }}$ Int. Geol. Cong. Part IV 490-506.

Qureshy M N, Brahmam N K, Gaurde S C and Mathur B K 1968 Gravity anomalies and the Godavari Rift India Geol. Soc. Amer. Bull. 79 1221-1230.

Radhakrishna B P 1989 Suspect Tectono-stratigraphic terrance elements in the Indian subcontinent; J. Geol. Soc. India 34 1-24.

Rai S N, Thiagarajan S and Ramana D V 2003 Seismically constrained 2-D thermal model of Central India along Hirapur-Mandla Deep Seismic Sounding profile across the Narmada Son Lineament; Curr. Sci. 85(2) 208-213.

Rai S N and Thiagarajan S 2006 A tentative 2D thermal model of central India across the Narmada-Son Lineament (NSL); J. Asian Earth Sci. 28 363-371. 
Rajendran K and Rajendran C P1998 Characteristics of the 1977 Jabalpur earthquake and their bearing on its mechanism; Curr. Sci. 74 168-174.

Rao N P, Tsukuda T, Kosuga M, Bhatia S C and Suresh G 2002 Deep lower crustal earthquakes in central India: Inferences from analysis of regional broadband data of the 21 May 1997 Jabalpur earthquake; Geophys. J. Int. $148132-138$

Rao R U M, Verma R K, Rao G V, Hamza V M, Panda P K and Gupta M L 1970 Heat flow studies in the Godavari Valley (India); Tectonophys. 10 165-181.

Ravi Shanker 1988 Heat flow map of India and discussions on its geological and economic significance; Indian Mineral 42(2) 89-110.

Ray R, Sheth H C and Mallik J 2007 Structure and emplacement of the Nandurbar-Dhule mafic dyke swarm, Deccan Traps, and the tectonomagmatic evolution of flood basalts; Bull. Volcanol. 69(5) 537-551.

Roy S and Rao R U M 2000 Heat flow in the Indian shield; J. Geophys. Res. 105(B11) 25,587-25,604.

Roy S, Sundar A and Rao R U M 1996 Heat flow studies in the Deccan Volcanic Province; Gondwana Geol. Mag. Spec. Vol. 2 475-484.

Rybach L and Cermak V 1982 Radioactive heat generation in rocks; In: Properties of rocks (ed.) H G Angenheister (Springer-Verlag) 1 353-371.

Rybach L and Buntebarth G 1984 The variation of heat generation, density and seismic velocity with rock type in the continental lithosphere; In: Terrestrial heat flow studies and the structure of the lithosphere (eds.) V Cermak, L Rybach and D S Chapman, Tectonophys. 103 $335-344$.
Safanda J, Kashubin S and Cermak V 1992 Temperature modelling along the Taratashisky profile crossing the Ural mountains; Studia Geophysica et Geodaetica 36 349-357.

Sheth H C, Mahoney J J and Chandrasekharam D 2004 Geochemical stratigraphy of Deccan flood basalts of the Bijasan Ghat section, Satpura Range, India; J. Asian Earth Sci. 23 127-139.

Shengbiao H and Jiyang W 2000 Heat flow, deep temperature and thermal structure across the orogenic belts in southeast China; J. Geodynamics 30 461-473.

Sridhar A R 2001 Crustal Seismic structure across the Western Narmada Zone (Thuadhara-Sendhwa-Sindad) with special emphasis on the structure up to the basement, Ph.D. Thesis, Osmania University, Hyderabad.

Sridhar A R and Tewari H C 2001 Existence of a sedimentary graben in the western part of Narmada zone: seismic evidence; J. Geodynamics 31 19-31.

Srivastava K and Singh R N 1998 A model for temperature variations in sedimentary basins due to random radiogenic heat sources; Geophys. J. Int. 135 727-730.

Srivastava K and Singh R N 1999 A stochastic model to quantify the steady-state crustal geotherms subject to uncertainties in thermal conductivity; Geophys. J. Int. 138 895-899.

Tewari H C, Murty A S N, Kumar P and Sridhar A R 2001 A tectonic model of the Narmada region; Curr. Sci. 80(7) 873-878.

Tewari H C and Kumar P 2003 Deep seismic sounding studies in India and its tectonic implications; J. Virtual Explorer 12 30-54.

West W D 1962 The line of Narmada-Son Valley; Curr. Sci. 31 143-144. 